\title{
Time Management in Travel and Tourism Companies in Jordan
}

\author{
Dr. Mohammad Nayef Alsarayreh (Corresponding author) \\ Educational Science and Social Department, AlBalqa Applied University, Jordan, Karak \\ E-mail: mohammad_n_k_s@yahoo.com
}

Dr. Mohammed Abdul Razzaq Abu Rumman

Business Administration, Albalqa applied University,Jordan,Al-Salt

Faculty of Planning and Management, Assistant Dean for Administrative Affairs

E-mail: abusharare_77@hotmail.com / aburumman@bau.edu.jo

Dr. Marwan M. Al-Nsour

The Faculty of Planning and Management, Business Administration Department

Al-Balqa’ Applied University, Salt, Jordan

Tel: (962)-77-740-9199Ｅ-mail: marwan_alnsour@yahoo.com

\author{
Omar (mohamad raouf) Hayajneh \\ Departmen of administration and financial sciences \\ AlBalqa Applied University, Jordan, Aqaba \\ E-mail: Omar_hia2011@hotmail.com
}

Received: October 6, 2011 Accepted: October 12, 2011 Published: January 1, 2012

doi:10.5296/jmr.v4i1.1005 URL: http://dx.doi.org/10.5296/jmr.v4i1.1005

\begin{abstract}
The study aimed to reveal the reality of time management in travel and tourism companies in Jordan through identifying the loss of time and the reasons for that, whether regulatory or
\end{abstract}


informational, and learn how efficient the management of choke points, and how quickly does customer requests are responded to.

The required data has been collected by questionnaire of 14 companies. The main findings of the study is that there is no waste of time in travel and tourism companies in Jordan due to organizational and informational aspect, with the exception of certain matters such as conflict of business goals, there isn't coordination between departments of the company, and there isn't renewed and up-to-date information for decision-maker when taking any decision. The study also found that they don't manage time of choke points efficiently, and they're quick to respond to customer orders, except that it does not provide new tourism products to customers in a rapid and up-to-date way

Most importantly, the study recommended tourism and travel companies in Jordan to work to eliminate or decrease conflict in work objectives, guide the company's departments towards coordination among them, provide up-to-date and renewed information continuously for decision maker, and manage choke points time more efficiently, as well as to provide new tourist products for customers in a rapid and up-to-date way.

Keywords: Tourism, Travel companies, Time management, Touristic companies 


\section{Introduction}

Organizations must have more interest in time as it is a scarce resources and it involves the various resources of the Organization, if time wasn't managed, nothing else will be managed. And a good management of time is useful in providing the resources and the costs of the Organization; the time element is the only productive component fairly distributed among organizations, unlike other production elements, therefore if this element is used efficiently and effectively it will reaches the efficiency in the functioning of the Organization, the Organization has specific objectives sought to be achieved by devoting all resources, possible investment and available abilities at hand including time.

Spending time without investing will be useless, what is required is to invest time to achieve the objectives of the Organization, it is like our capital if it hasn't been invested it is lost, but if it is invested it will continue to grow and bear fruit in the future. So we must be aware that there are cost implications if we wasted time and invested poorly.

Time management varies in difficulty from on facility to another depending on the type and nature of the sector. In the tourist sector it seems difficult as products are intangible, heterogeneous, uneven and difficult to predict. Therefore the management companies operating in this sector must do more than care for achieving greater effectiveness of available time to all corners of the organization.

Travel and tourism companies offer many different services contributed significantly to the operation and development of many segments of the tourism sector and other sectors directly and indirectly. The nature and size of these companies and its quality, affect these sections and sectors. One of the most important things that needs attention to improve performance and meet customer requests quickly, is the management control and guidance of time to the best investment through good organization and provision of appropriate information systems and management of the chock points stations efficiently.

\section{Previous studies}

Study Alharahashh, Mohammad (2009) the study aimed to identify the viewpoint of administrators in Al-Bayt University towards the degree of effective time management. The study found that effective time management were high, the study recommended to spread awareness of the importance of official time to employees which will give the university back positive results.

Study of Abu Samra (2007): weghnim, the study aimed to identify leadership styles of academic department's heads in community colleges in Palestine and its relation with time management, the study concluded that the estimates sample time of management reality was moderate, and there is a positive relationship between leadership style and the reality of time management.

Study Almuhtaseb and Jalloud (2006), the study aimed to describe the relationship of time management with work pressure and social responsibilities, the study found that there wasn't a strong influence of work pressure over the efficient and effective time management, where 
as gossip and controversy are the most important time wasting. The study recommended to reduce the administrative and bureaucratic complexities, and the use of modern means and methods of internal communication.

Study of Al Joofee (2004), The study aimed to evaluate operations of official time management in the university of $\mathrm{Ab}$, the study found that the formal time for the requirements of the daily administrative job in the University of $\mathrm{Ab}$ is enough to accomplish the tasks. Administrative officers lacked functional awareness of time management and investment importance, towards the requirements of his or her official position. The most important thing the study recommended is to establish administrative unit dealing with the process of planning and follow-up in the University.

Study of Al -Washah (2004), the study aimed to identify trends in Central Administration directors working in the institutions which work in qualified industrial areas toward time management and effectiveness of time management. The study found that there is positive trends among these managers about time management and exploitation leading to efficiency and positivneness. The study recommended the adoption of clear action plans within the institution which leads to providing time to employees.

Study of Al-Omarey (2002), the research aims to identify the real time management of Deans faculties of Applied University of Balqa ' in Jordan. The study found that deans have good time management, and their leadership is over the average, with a very good level of creative leadership. The most recommended by the study is the need to use ready-made models in correspondence, and considering time management crucial to the dean effectiveness

Study Guoqing\&Yongxin, 2000, The study aimed to identify gender differences between Chinese managers in time management, it was found that female managers are less effective in managing time than male managers, but there was no difference between males and females in regard to their views about what waste time.

\section{The problem of the study}

The problem lies in the lack of clarity in how to manage time in travel and tourism companies, so there are questions if there is a waste of time for regulatory and informational reasons, and if these companies manage chock points stations time efficiently and whether it meets the quick customer orders.

\section{The importance of the study}

It is important to recognize the reality of time management in travel and tourism companies in Jordan because of its usefulness in detection of deficiencies if it is found, and strengthening the costiveness and make it effective, this in turn increases the efficiency and effectiveness of the performance, increase profitability, competitiveness, and stimulating the tourism sector in general like hotels, tourist sites, shrines and other tourism sites related to this sector. And the scarcity of this study makes it more important.

\section{Study objectives}




\section{Macrothink}

The study aims to indicate whether there is a waste of time in travel and tourism companies in Jordan and define the reasons if present, whether organizational, informational, or mismanagement of choke points. As well as learn how quickly customers demands are met in various phases related to that.

\section{Methodology of the study}

The study used the analytical and descriptive approach, where preliminary data were collected from the study society and analyzed statistically to analyze and test hypotheses and reach the results related to the study areas.

\section{Society and the study sample}

Study community consists of travel and tourism companies, 14 companies have been selected randomly as a sample.

\section{The study hypotheses}

Study tests the following hypotheses:

Hypothesis 1:

There is a waste of time in travel and tourism companies in Jordan due to the regulatory area.

The second premise:

There is a waste of time in travel and tourism companies in Jordan return to informational domain.

The third hypothesis:

Travel and tourism companies in Jordan do not manage choke points time efficiently.

Hypothesis 4:

Travel and tourism companies in Jordan do not respond to customer orders quickly

\section{Survey tool}

Questionnaire is the primary data collection tool that is designed to measure the fact in the study sample. 200 questionnaires have been distributed to all employees who are able to answer. 169 valid for analysis questionnaire were recovered. The questionnaire was based on closed questions, with answers available (strongly agree, agree, neutral, disagree, and strongly disagree). And the previous answers have been weighting by degrees $(5,4,3,2,1)$ respectively.

\section{Persistence tool}

* Persistence tool has been tested by testing Cronbach's Alpha coefficient, given in table (1) shows the following:

-Alpha value of organizational domain dimension of 0.75 . 
-Alpha value of the informational dimension domain 0.88 .

-Alpha value of choke points dimension 0.71

-Alpha value of to meeting the demands of customers dimension 0.79 .

-Alpha value for all paragraphs 0.82

All these values higher than 0.60 which means that there is a persistence in the study tool. 
Table 1. the Cronbach's Alpha values for the dimension of study

\begin{tabular}{|l|l|}
\hline Dimension & Cronbach's Alpha \\
\hline Organizational domain & 0.75 \\
\hline Informational domain & 0.88 \\
\hline Choke points & 0.71 \\
\hline Meeting customers demands & 0.79 \\
\hline Total & 0.82 \\
\hline
\end{tabular}

\section{Description of personal and functional factors of respondents}

Table No. (2) Shows a description of personal and functional factors of the study sample members, as follows:

\section{* Specialization:}

$25.44 \%$ of sample were tourist management specialty,

$24.26 \%$ of the sample were business administration

$21.89 \%$ of the sample were tourism specialty,

$10.06 \%$ of the sample were accounting specialty,

$6.51 \%$ of the sample were economy,

$11.84 \%$ from other disciplines.

\section{* Academic qualification:}

$60.36 \%$ of the sample study were BS holders,

$28.40 \%$ of the sample study were diploma,

$8.28 \%$ of the sample study were masters ,

and $2.96 \%$ of the sample study were from general secondary recipients.

\section{* Years of experience:}

$33.73 \%$ years of experience range is between 6-10 years.

$30.18 \%$ years of experience range between $11-15$ years,

27.81\% years of experience range between 1-5 years.

$8.28 \%$ years of experience range $15+$ years. 
* Job level: the table shows that

$53.25 \%$ of the samples are employee

$25.45 \%$ of the samples are section chiefs,

$15.38 \%$ of the samples are Deputy Director

$5.92 \%$ of the samples are from managers.

Table 2. duplicates and the percentages of variables of personal respondents:

\begin{tabular}{|c|c|c|c|}
\hline Variable & & frequency & $\%$ \\
\hline \multirow{6}{*}{ Specialization } & business administration & 41 & 24.26 \\
\hline & Accounting & 17 & 10.06 \\
\hline & economy & 11 & 6.51 \\
\hline & Managing traveler & 43 & 25.44 \\
\hline & Tourism & 37 & 21.89 \\
\hline & Another & 20 & 11.84 \\
\hline \multirow{4}{*}{ Educations } & secondary & 5 & 2.96 \\
\hline & Diploma & 48 & 28.40 \\
\hline & BA & 102 & 60.36 \\
\hline & Master & 14 & 8.28 \\
\hline \multirow{4}{*}{ Years of experience } & $1-5$ & 47 & 27.81 \\
\hline & $6-10$ & 57 & 33.73 \\
\hline & $11-15$ & 51 & 30.18 \\
\hline & More than 15 & 14 & 8.28 \\
\hline Career level & Director & 10 & 5.92 \\
\hline
\end{tabular}




\begin{tabular}{|l|l|l|l|}
\hline & Deputy Director & 26 & 15.38 \\
\cline { 2 - 4 } & Head of section & 43 & 25.45 \\
\cline { 2 - 4 } & Employee & 90 & 53.25 \\
\hline
\end{tabular}

\section{Test and analysis of assumptions}

Hypothesis 1:

There is a waste of time in travel and tourism companies in Jordan due to the organizational field.

Table 3 shows the following:

With the exception of paragraphs 3 and 7, all other paragraphs have obtained $\quad .1$ arithmetic mean greater than 3.00 , and indicators less than 0.05 , which means it is statistically significant, that indicate that all these things existed in these companies. Paragraph No. 6

which measure how clear are the tasks assigned to the employees came first with 4.02 arithmetic mean. Paragraph No. 4 ranked second with arithmetic mean 3.76. Paragraph No. 5 ranked last with the statistically acceptable in paragraphs and with arithmetic mean 3.69.

Paragraph No. 3 got arithmetic mean less than 3.00 it is not statistically significant, $\quad .2$ which indicates a conflict in business objectives.

paragraph No. 7 has got a arithmetic mean greater than 3.00 but the indicator was $\quad .3$ greater than 0.05 which means that it is not statically significant, this indicates that there isn't coordination between departments of the company.

All paragraphs which represent the organizational field has got 3.56 arithmetic mean, .4 0.00 indicators level which is less than 0.05 . Which means that the first hypothesis is rejected, i.e. that there is no waste of time in travel and tourism companies in Jordan due to the organizational field.

Table 3. Arithmetic mean, standard deviation, the $t$ value and observation level of the organizational field:

\begin{tabular}{|l|l|l|l|l|l|}
\hline $\begin{array}{l}\text { Item } \\
\text { No. }\end{array}$ & Item & $\begin{array}{l}\text { arithmetic } \\
\text { mean }\end{array}$ & $\begin{array}{l}\text { standard } \\
\text { deviation }\end{array}$ & $\begin{array}{l}\mathrm{t} \\
\text { value }\end{array}$ & $\begin{array}{l}\text { indicators } \\
\text { level }\end{array}$ \\
\hline 1 & $\begin{array}{l}\text { objectives of my position clear and } \\
\text { definite }\end{array}$ & 3.74 & 1.23 & 7.92 & 0.00 \\
\hline 2 & $\begin{array}{l}\text { there is no duplication in work } \\
\text { objectives and policies }\end{array}$ & 3.72 & 1.20 & 7.79 & 0.00 \\
\hline
\end{tabular}




\begin{tabular}{|l|l|l|l|l|l|}
\hline 3 & $\begin{array}{l}\text { there is no contradiction in the } \\
\text { objectives work }\end{array}$ & 2.91 & 1.26 & -0.98 & 0.33 \\
\hline 4 & $\begin{array}{l}\text { there is a precise job description of } \\
\text { my work duties }\end{array}$ & 3.76 & 1.15 & 8.43 & 0.00 \\
\hline 5 & $\begin{array}{l}\text { there is precise description of my } \\
\text { positions authorities }\end{array}$ & 3.69 & 1.13 & 7.86 & 0.00 \\
\hline 6 & $\begin{array}{l}\text { tasks entrusted to me is clear and } \\
\text { uncomplicated }\end{array}$ & 4.02 & 0.93 & 14.28 & 0.00 \\
\hline 7 & $\begin{array}{l}\text { there sufficient coordination } \\
\text { between the company tourist } \\
\text { departments }\end{array}$ & 3.05 & 1.40 & 0.50 & 0.62 \\
\hline & \begin{tabular}{l} 
Total \\
\hline
\end{tabular}
\end{tabular}

The second premise:

There is a waste of time in travel and tourism companies in Jordan due to informational field.

Table 4 shows the following:

With the exception of paragraphs 9,11,13, all other paragraphs got Arithmetic mean $\quad .1$ greater than 3.00 , and indication level less than 0.05 , which means that it is statistically significant, i.e. these things exist statistically. Paragraph No.10 which measures the availability of enough feedback at the appropriate time came first with 4.04 arithmetic mean, Paragraph No. 12 ranked second with arithmetic mean 3.47. paragraph No. 8 ranked third and final with statistically acceptable paragraphs and 3.44 arithmetic mean

paragraph No. 9 have arithmetic mean less than 3.00 which means that it is not $\quad .2$ statistically significant, i.e. that there is not continuous, sufficient and updated staff meetings to make staff acquainted with the new development at work .

paragraph No. 11 got arithmetic mean greater than 3.00 but the level of indication $\quad .3$ was greater than 0.05 , which means it is not statistically significant i.e. there are no renewed and up-to-date information for decision-maker when adopting any decision

Paragraph 13 got a arithmetic mean less than 3.00, i.e. it is not statistically significant, $\quad .4$ meaning that there are not enough informational sources devices available.

All paragraphs which represent the informational field has got a arithmetic mean 3.30, $\quad .5$ 0.00 level of indication which is less than 0.05 . That means the second hypothesis is rejected, 
i.e. there is no waste of time in travel and tourism companies in Jordan return to information

field.

Table 4. Arithmetic mean, standard deviation, the $t$ value and observation level of the informational field:

\begin{tabular}{|l|l|l|l|l|l|}
\hline Item & Item & $\begin{array}{l}\text { arithmetic } \\
\text { mean }\end{array}$ & $\begin{array}{l}\text { standard } \\
\text { deviation }\end{array}$ & $\begin{array}{l}\mathrm{t} \\
\text { value }\end{array}$ & $\begin{array}{l}\text { indicators } \\
\text { level }\end{array}$ \\
\hline 8 & $\begin{array}{l}\text { The communication systems I used } \\
\text { are clear }\end{array}$ & 3.44 & 1.36 & 4.18 & 0.00 \\
\hline 9 & $\begin{array}{l}\text { There is not continuous, sufficient and } \\
\text { updated staff meetings to make staff } \\
\text { acquainted with the new development } \\
\text { at work. }\end{array}$ & 2.96 & 1.30 & -0.35 & 0.72 \\
\hline 10 & $\begin{array}{l}\text { availability of enough feedback at the } \\
\text { appropriate time }\end{array}$ & 4.04 & 1.06 & 12.67 & 0.00 \\
\hline 11 & $\begin{array}{l}\text { there are renewed and up-to-date } \\
\text { information for decision-maker when } \\
\text { adopting any decision }\end{array}$ & 3.09 & 1.01 & 1.22 & 0.23 \\
\hline 12 & $\begin{array}{l}\text { information available when making } \\
\text { any decision are appropriate }\end{array}$ & 3.47 & 1.29 & 4.72 & 0.00 \\
\hline 13 & $\begin{array}{l}\text { There are enough available } \\
\text { informational sources devices. }\end{array}$ & 2.82 & 1.37 & -1.74 & 0.08 \\
\hline
\end{tabular}

The third hypothesis:

Travel and tourism companies in Jordan do not to manage choke points time efficiently

Table 5 shows that, with the exception of paragraph 15, all other paragraphs got arithmetic mean less than 3.00, it is not statistically significant, meaning that these things aren't statistically available. Paragraph No. 15 has got a arithmetic mean greater than 3.11 and indication level less than 0.05 , it is statistically significant i.e. choke points are set at a fully operational level to provide tourism services for customers.

All paragraphs which represents the chock points stations management has got 2.73 arithmetic mean, it is less than 3.00. Which means that the third hypothesis is acceptable, i.e., travel and tourism companies in Jordan don't manage choke points time efficiently. 
Table 5. Arithmetic mean, standard deviation, the t value and observation level of the chock points

\begin{tabular}{|c|c|c|c|c|c|}
\hline $\begin{array}{l}\text { Item } \\
\text { No. }\end{array}$ & Item & $\begin{array}{l}\text { arithmetic } \\
\text { mean }\end{array}$ & $\begin{array}{l}\text { standard } \\
\text { deviation }\end{array}$ & $\begin{array}{l}\mathrm{t} \\
\text { value }\end{array}$ & $\begin{array}{l}\text { indicators } \\
\text { level }\end{array}$ \\
\hline 14 & choke points are accurately defined & 2.72 & 1.31 & -2.83 & 0.01 \\
\hline 15 & $\begin{array}{l}\text { choke points are set at a fully } \\
\text { operational level to provide tourism } \\
\text { services }\end{array}$ & 3.39 & 1.33 & 3.81 & 0.00 \\
\hline 16 & $\begin{array}{l}\text { to reduce pressure on choke points } \\
\text { work in other centers is adapted }\end{array}$ & 2.36 & 1.33 & -6.31 & 0.00 \\
\hline 17 & $\begin{array}{l}\text { efficiency and effectiveness of the } \\
\text { chock points is constantly increased by } \\
\text { working on using the latest } \\
\text { technological methods to provide } \\
\text { tourist service }\end{array}$ & 2.92 & 1.37 & -0.73 & 0.47 \\
\hline 18 & $\begin{array}{l}\text { More focus is given to most profitable } \\
\text { tourism products in the choke points } \\
\text { such as booking plane tickets instead of } \\
\text { bus ticketing }\end{array}$ & 2.42 & 1.29 & -5.83 & 0.00 \\
\hline 19 & $\begin{array}{l}\text { strategic plans are put to face } \\
\text { (emergency situations) to address time } \\
\text { management in the choke points such } \\
\text { as increasing demand for corporation } \\
\text { tourist services at specific periods of } \\
\text { year }\end{array}$ & 2.60 & 1.11 & -4.69 & 0.00 \\
\hline & Total & 2.73 & 0.74 & -4.66 & 0.00 \\
\hline
\end{tabular}

Hypothesis 4:

Travel and tourism companies in Jordan do not to meet rapid customer orders.

Table 6 shows the following:

with the exception of paragraph No. 20, all other paragraphs have got arithmetic mean larger than 3.00, and indication level less than 0.05 , which means that it is statistically significant, meaning that all these things statistically existed. Paragraph No. 22 which 
measures continuous tourist offers for tourism products ranked first and with 4.00arithmetic mean. Whereas paragraph 23 ranked second place and by arithmetic mean 3.96. Paragraph

No. 24 came last in statistically acceptable paragraphs with arithmetic mean 3.51.

Paragraph No. 20 has got arithmetic mean less than 3.00 and is not statistically $\quad .2$ significant and this shows that companies do not provide new tourism products to customers in renewed and rapid way.

All paragraphs which meet the demands of the customers has got a arithmetic mean $\quad .3$ 3.59, with 0.00 indication level which is less than 0.05 . i.e. fourth hypothesis which states that travel and tourism companies in Jordan meet rapid customer is rejected

Table 6. Arithmetic mean, standard deviation, the t value and observation level of meeting the demands of customers

\begin{tabular}{|c|c|c|c|c|c|}
\hline $\begin{array}{l}\text { Item } \\
\text { No. }\end{array}$ & Item & $\begin{array}{l}\text { arithmetic } \\
\text { mean }\end{array}$ & $\begin{array}{l}\text { standard } \\
\text { deviation }\end{array}$ & $\begin{array}{l}\mathrm{t} \\
\text { value }\end{array}$ & $\begin{array}{l}\text { indicators } \\
\text { level }\end{array}$ \\
\hline 20 & $\begin{array}{l}\text { company provide new tourism } \\
\text { products to customers in a renewed } \\
\text { and rapid ways }\end{array}$ & 2.59 & 1.15 & -4.63 & 0.00 \\
\hline 21 & $\begin{array}{l}\text { customer requests for tourism } \\
\text { products are received and met fast }\end{array}$ & 3.69 & 1.14 & 7.87 & 0.00 \\
\hline 22 & $\begin{array}{l}\text { Continuous presentations is made for } \\
\text { tourist products }\end{array}$ & 4.00 & 0.96 & 13.49 & 0.00 \\
\hline 23 & tourist servicing is done quickly & 3.96 & 1.00 & 12.44 & 0.00 \\
\hline 24 & $\begin{array}{l}\text { tourist programs are quickly made } \\
\text { according to the market demands }\end{array}$ & 3.51 & 1.26 & 5.24 & 0.00 \\
\hline 25 & $\begin{array}{l}\text { tourist offerings are continuously } \\
\text { published for customers through the } \\
\text { use of newer and faster roads such as } \\
\text { the Internet }\end{array}$ & 3.81 & 0.98 & 10.80 & 0.00 \\
\hline & Total & 3.59 & 0.55 & 13.96 & 0.00 \\
\hline
\end{tabular}

\section{Conclusion:}

The study reached the following results: 
No waste of time in travel and tourism companies in Jordan due to the organizational $\quad .1$ field. Since the objectives of personnel's are specific and clear, there is no duplication of work objectives and policies, there is accurate job description of work duties, and there is precise description for the authorities and functions. However, there is a conflict in business objectives, and there is no coordination between departments of the company.

There is no waste of time in travel and tourism companies in Jordan due to $\quad .2$ informational field in general, where there is clarity in communication systems, availability of enough feedback at the appropriate time and appropriate information are available when making any decision. But there are deficiencies in some areas i.e. There is not continuous, sufficient and updated staff meetings to make staff acquainted with the new development at work, there isn't renewed and up-to-date information for decision-maker when adopting any decision, and sources of information is not totally available

the travel and tourism companies in Jordan don't manage chock point time efficiently, 3 with the exception that the chock points are put at full operation to provide tourism services for customers, choke points are not accurately defined, work in other centers is not adapted to reduce pressure on choke points, there is no working to increase the efficiency and effectiveness of choke points, there isn't constantly focusing on most profitable tourism products in the choke points, and there aren't strategic plans to cope with emergency situations.

Travel and tourism companies in Jordan work to meet rapid customer orders. Where $\quad .4$ customer orders are received for tourism products and met quickly, tourist offers for touristic products are continuously presented; tourism services and tourist programs are presented quickly and according to the need and demand of market tourism offers are published for customers continuously through the use of newer and faster roads such as the Internet. But they do provide tourism products for customers in a rapid and regenerated way

\section{Recommendations}

The study recommends that:

Travel and tourism companies in Jordan should continue to strengthen the role of the $\quad .1$ organizational, informational, and positive field in time management and reducing time losses to reach better results.

Tourism and travel companies in Jordan should work to eliminate or reduce conflict $\quad .2$ in business objectives.

There should be greater coordination between the departments of tourism and travel $\quad .3$ companies in Jordan and creation of appropriate conditions for that.

Tourism and travel companies in Jordan should have continuous, sufficient and $\quad .4$ updated staff meetings to make staff acquainted with the new development at work.

Providing continuously, up-to-date and renewed information for decision maker to $\quad .5$ use when they need to take decisions. 
Tourism and travel companies in Jordan should provide enough sources of $\quad$.6 information.

travel and tourism companies in Jordan should manage choke points time more $\quad .7$ effectively, by identifying choke points accurately, adaptation of work in other centers to reduce pressure on choke points, increasing the efficiency and effectiveness of the performance of the choke points centers constantly, focusing on the most profitable tourism products in these choke points, and develop strategic plans to address emergencies.

travel and tourism companies in Jordan should provide for customers renewed and $\quad .8$ rapid new tourist products

\section{References}

Abu Hashish, K. (2005). Cost accounting, Dar Wael Publishing, Amman, Jordan.

Abu-Nassar, M. (2010). Managerial accounting, Dar Wael Publishing, Amman, Jordan.

kapuge , A ., Smith , M . (2007). Management Practices and Perfomance, Reporting in the Sri lankan, 76(11), 28 - 30.

Zanini , T. (2007) . Monitoring of Quality Costs in the Croatian Hotel Industry. Organizacija, 4.

James, A. (1990). Management Information Systems, A Managerial End User Perspective, Irwin Homewood.

Robert Kaplan, S., Anthony, A, A. (1998). Advanced Management Accounting, third Edition, Prentice Hall, New Jersey.

Liebowttz , J. (1999). Information Systems: Success or Failure, Journal of Computer Information Systems, 1.

Guoqing,Y. (2000). Gender Differences of China's Manager inTime Management. Women in Management Review.

Abu Samra, M., ghuneim, M. (2007). leadership style of the academic section chiefs in community colleges in Palestine and their relationship to time management, Journal of the Association of Arab universities, 48,363-317.

Al-Jrah, M. (2002). The impact of information technology standard used in Jordanian commercial banks on the efficiency of its financial performance, MPhil-Gezira University-Sudan.

Al-Joofee, M, A. (2004). Effective time management in the Eb University, the University researcher, 6, 77-108.

Alharahashh, M, A. (2009). The viewpoint of administrators in Bayt University towards the degree of effective time management, Journal of the Association of Arab universities, 54, 35-366. 


\section{Macrothink}

Journal of Management Research ISSN 1941-899X 2012, Vol. 4, No. 1: E8

Ramadan, H. (1999). Factors affecting accounting information systems in Jordanian industrial public shareholding corporations, unpublished MPhil, University of Jordan, Jordan.

Kahaleh, J., Hanan, R. (2004). management accounting, first edition, Al-Dar Al Ilmeeah al Dawleeh and Dar al Thakafa wa Al Nasher, Amman, Jordan.

Tarawneh, M, A. (2002). Time management and functionality, comparison analysis study, research and studies at mu'tah,17(1),63-93.

Al-Omaree, S, A. (2002). Time management and its relationship with the creative leadership of Deans in Balqa ' applied University in Jordan, unpublished dissertation, Baghdad University.

Gorab, K. and Hijazi, F. (2003). Management information systems: an integrated introduction, Al-Ish'a' library, Cairo, Egypt.

Al-Mouhtaseb, L, H., \& Marwan, S. (2006). Effectiveness of time management to employees in Palestinian universities: a study of field applied in Hebron-Palestine, Journal of the Association of Arab universities, 47, 177-206.

Al-Wahah, W, M. (2002). Central management trends in institutions working in the Qualified industrial region toward time management, unpublished MPhil, Yarmouk University, Jordan. 